\title{
THE FINANCIAL HEALTH OF PUBLIC LIMITED COMPANIES IN POLAND
}

\author{
[Finanční zdraví veřejně obchodovatelných společností v Polsku] \\ Tomáš Pražák ${ }^{1}$ \\ ${ }^{1}$ Silesian University, School of Business Administration, Univerzitní nám. 1934/3, 73340 Karvina \\ Email: prazak@opf.slu.cz
}

\begin{abstract}
The financial performance and financial health of companies is given through the ability to generate added value. For the resulting effect of creating added value, maximum activity is required. Otherwise, companies have significant payment difficulties that can be resolved by a radical change in its activities or structure. The aim of this paper is to indicate potential threat of the financial distress of selected public limited companies in Poland. The financial health of companies is analysed by Taffler's bankruptcy model. The construction of the predictive models and the bankruptcy models are based on actual data from companies which were threatened by bankruptcy in previous years. The Taffler's bankruptcy model is applied on the annual financial results of public limited companies in Poland from 2006 to 2015. The results indicated that $12 \%$ of public limited companies in Poland had financial problems during observed period.
\end{abstract}

Keywords: financial health, Pearson correlation coefficient, Poland, public limited companies, Taffler's bankruptcy model.

JEL classification: C53, M21, G33

Doručeno redakci: 20.9.2017; Recenzováno: 11.10.2017; 16.10.2017; Schváleno k publikování: 13.12.2017

\section{Introduction}

The increasing trend of trading on capital markets is linked to high capital mobility and the need to rapidly assess the financial situation of companies traded on these markets. In such an environment, it becomes a necessity for companies to apply modern methods of financial management to help maintain competitiveness and financial health.

The financial performance and financial health of an enterprise is necessary to the ability to generate added value, return on the capital invested, or return on inputs. For the resulting effect of creating value added, maximum activity is required, which is one of the basic prerequisites for an effective appreciation of the funds. A financially healthy companies has an effective amount of capital available to cover assets, is able to meet its financial obligations and has the ability to convert individual assets into the cash. Such an enterprise is attractive to investors, higher attractiveness will subsequently be reflected in their interest in investing and capitalizing on capital through the development of new activities or the strengthening of the position on the capital market.

In the financial management, a number of methods are used to identify financial health. The basic process is to develop a financial analysis based on ratios of profitability, liquidity, debt, or activity. Apart from these partial analyses, more complex discriminatory functions are used for the financial situation of the enterprise, which are able to identify the potential financial distress of the enterprise.

The company's financial distress occurs in situations where an enterprise has significant payment difficulties that cannot be resolved only by a radical change in its activities or structure. Bankruptcy models (Altman bankruptcy model, Taffler's bankruptcy model, or IN indexes of 
trust) are used as early warning systems against possible financial distress to capture events typical of the future bankruptcy of a business.

Bankruptcy models are used to predict the company's financial problems or determine the degree of imminent threat to the company by bankruptcy. This type of model is based on actual data from a very wide range of companies. For the overall assessment of the financial situation of the company, it is also necessary to take into account the results of partial analyses of individual business areas. For this reason, it is advisable to construct bankruptcy models following financial analysis using absolute and ratio ratios.

A financially distressed firm often suffers from lack of liquidity and needs timely bridge financing in the process of resolving financial distress. The distressed firm needs sufficient cash to pay employees, suppliers, and other stakeholders. The distressed firm may also have a positive net present value projects available that need to be funded. Thus, the firm's ability to attract new capital is crucial for the company's survival and investment efficiency. In the event of financial however, additional funding may be difficult to obtain due to the high risk involved lending to the distressed firm and the "debt overhang" problem.

According to Mokhova and Zinecker (2013), the development of insolvency proceedings is mainly influenced by macroeconomic environment. In times of economic recession, the number of firms' bankruptcies usually increases, whereas in the conjuction period, their number declines. The aim of this study is to estimate the model of the proportion of economic entities that are experiencing a significant deterioration in their economic conditions, which can lead to bankruptcy in the extreme.

The aim of this paper is to indicate potential threat of the financial distress of selected public limited companies in Poland. Poland is recognised as a regional economic leader within Central and Eastern Europe, with nearly 40 percent of the 500 biggest companies in the region (by revenues) as well as a high globalisation rate. By contrast, Poland has the highest number of enterprise deaths in the reference period in Central and Eastern Europe. The Taffler's bankruptcy model is applied on the annual financial results of public limited companies in Poland from 2006 to 2015 to indicate companies with potential financial problems and eliminate the risk of potential bankruptcy of a business.

The remainder of this paper is organized as follows. The relevant literature is reviewed in Section 2. The data and the methodology used in this paper are introduced in Section 3. The results of the empirical estimation are reported in Section 4. The conclusions and summary of the main findings are contained in Section 5.

\section{Literature Review}

The main causes of the financial distress of businesses were dealt with in Altman (2006) or Senbet and Wang (2012). The most frequent causes of financial distress are inadequate legislation, macroeconomic factors, deregulation in key industries (financial services, aviation, health, energy industry) or growing international competition and globalization. The financial difficulties are most often faced by new business sectors, thanks to a high degree of optimism at the start of business, as well as industrial sectors that are often affected by crises (textile, agriculture or the financial sector).

Fundamental models for predicting financial distress and business bankruptcy based on financial indicators are the Beaver (1966) and Altman (1968) models. Predictive models are 
based on the hypothesis that the financial difficulty of an enterprise can be identified using the ratios of financial ratios before it actually becomes apparent. The construction of the predictive models and the bankruptcy models are based on actual data from companies which were threatened by bankruptcy in previous years.

On this bases, the Taffler's bankruptcy model was developed (1983). The first stage in constructing this model was to compute over 80 selected ratios from the accounts of all listed industrial firms failing between 1968 and 1976 and 46 randomly selected solvent industrial firms. The Taffler model's ratios and coefficients indicate the four key dimensions of the firm's financial profile that are being measured by the selected ratios. These dimensions, identified by factor analysis, are: profitability, working capital position, financial risk and liquidity.

Agarwal and Taffler (2007) confirmed the predictive ability of the model over the years and also demonstrate the predictive ability of the published accounting numbers and associated financial ratios used in the $\mathrm{z}$-score model calculation.

Several studies on companies' failure and financial distress were also performed in Central and Eastern European countries. According to studies by Lizal (2002) for the Czech Republic or by Hajdu and Virag (2001) for Hungary, they confirmed the importance of bankruptcy models. Financial distress of companies in Poland was the aim of the study by Gruszczynski (2004). The financial condition of companies in Poland was determined by the degree of liquidity, profitability, and the financial leverage variables. The forecast accuracy of the estimated models lies in the range of $80-90 \%$ in short horizon. Similarly, Fijorek and Grotowski (2012) found a clear group of financial ratios that seem to be very helpful when predicting bankruptcy in Poland. These are: the cash turnover ratio, the operating profitability, the return on sales, the current liabilities to total assets ratio, the equity to assets ratio and the total assets turnover. They also confirmed the strong predictive ability of bankruptcy models for maximum two years horizon.

The high predictive value of the financial distress in the models, according to the study Liou and Smith (2007) have macroeconomic indicators. This relationship is most often explored in the conditions of developed economies. In general, they concluded that the number of bankruptcies is increasing during the economic recession, while in the conjunction period their number decreases. According to them and Wadhwani (1986), other significant indicators, which affect the number of companies at risk of financial distress or the default of enterprises are inflation rate, nominal and real interest rates, wage levels or aggregate demand.

Based on the literature review, among the most significant macroeconomic variables that have the most significant influence on the financial situation of companies are GDP, interest rates, inflation rate, tax rates, exchange rate or unemployment rate. These indicators play an important role in defining internal and external economic equilibrium, which is also reflected in the functioning of individual businesses and sectors.

The most frequently mentioned factor is an indicator of GDP, which is based on the standard of living or income of the population. Its impact on the economy depends on the difference between the actual and the potential product. If the product is below its potential level (recessive gap), there is no full use of the production factors. Otherwise (the inflation gap), the inflationary pressures on the economy are causing an overheating of the economy. The relationship between GDP growth rates and the financial situation of an enterprise is generally positive, with higher output and consumption increasing corporate profits and fund shares. 


\section{Data description and Methodology}

The aim of this paper is to indicate potential threat of the financial distress of selected public limited companies in Poland. Poland is a regional power as well as a possible emerging world power. It has the eighth largest and one of the most dynamic economies in the European Union, simultaneously achieving a very high rank on the Human Development Index. Additionally, the Warsaw Stock Exchange is the largest and most important in Central and Eastern Europe. Poland is a developed and democratic country, which maintains a high-income economy along with very high standards of living, life quality, safety, education and economic freedom.

\subsection{Economic characteristic of Poland}

Fig. 1 described GDP growth per capita in select Central and Eastern European countries. Poland's economy is considered to be one of the fastest growing within the EU. Poland is the only European economy to have avoided the global financial crises in 2009, because of a strong domestic market, low private debt, flexible currency, and not being dependent on a single export sector.

Figure 1: GDP growth per capita in Central and Eastern European countries

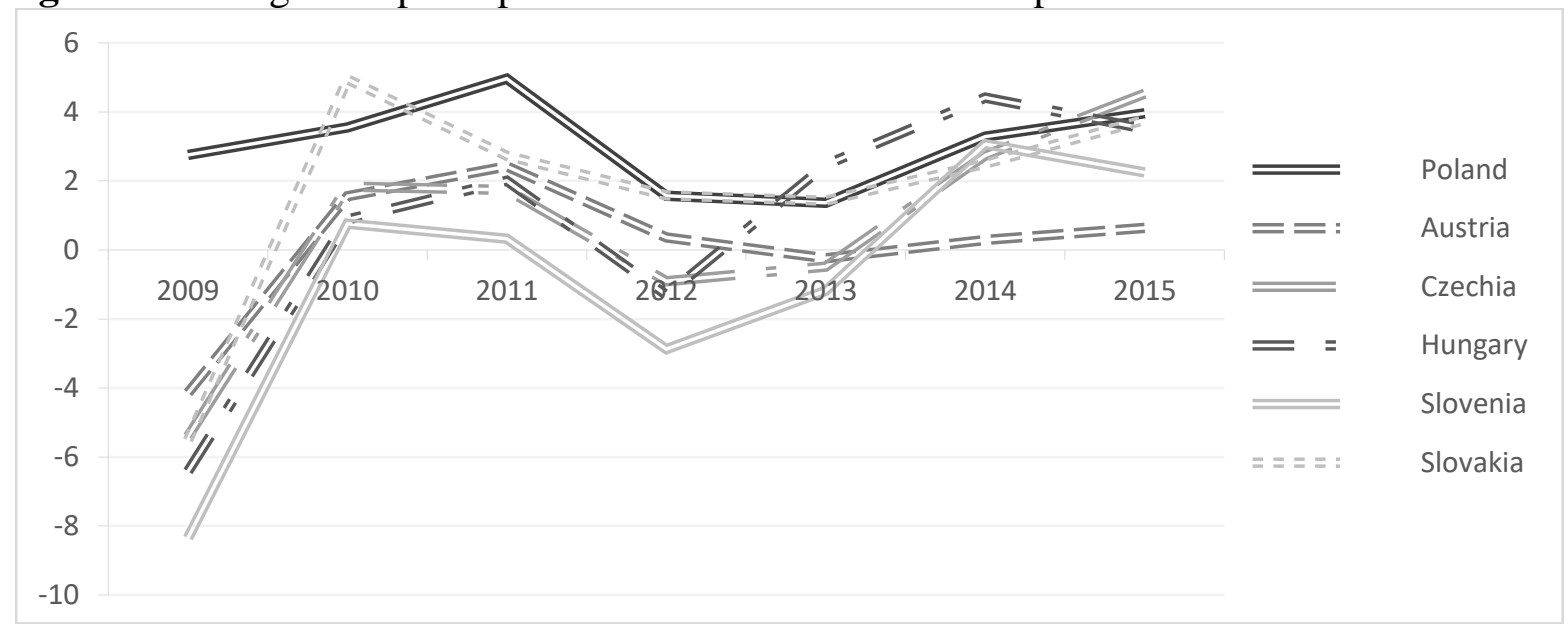

Source: Eurostat

Poland is a regional giant when it comes to business, but it's also increasingly competitive in the international context. The Deloitte Central Europe Top 500 report illustrates that 180 of the 500 biggest companies in the region (by revenues) are located in Poland. It has weathered the economic downturn in Europe far better than most countries, but the business environment still remains a challenging one, and having local help is crucial in navigating tax laws and compliance issues. Structural economic reforms, but also reforms in health care, education, the pension system, and state administration have resulted in larger than expected fiscal pressures. The next problem of polish companies could be at the foundation of business, when starting new business can be a rather long process in Poland.

The World Bank and International Finance Corporation rank Poland in $161^{\text {st }}$ place in the world for ease of dealing with construction permits, signalizing the rigorous nature of the process. These founding could be possible reasons for high death rate of companies in Poland captured in Fig. 2. Death rate is measured as a number of enterprise deaths in the reference period divided by the number of enterprises active and polish companies has the highest average death rate around 11.40 in observed period, what is more than one-point higher rate than in Hungary and Slovakia. 
Figure 2: Death rate of companies in Central and Eastern European countries

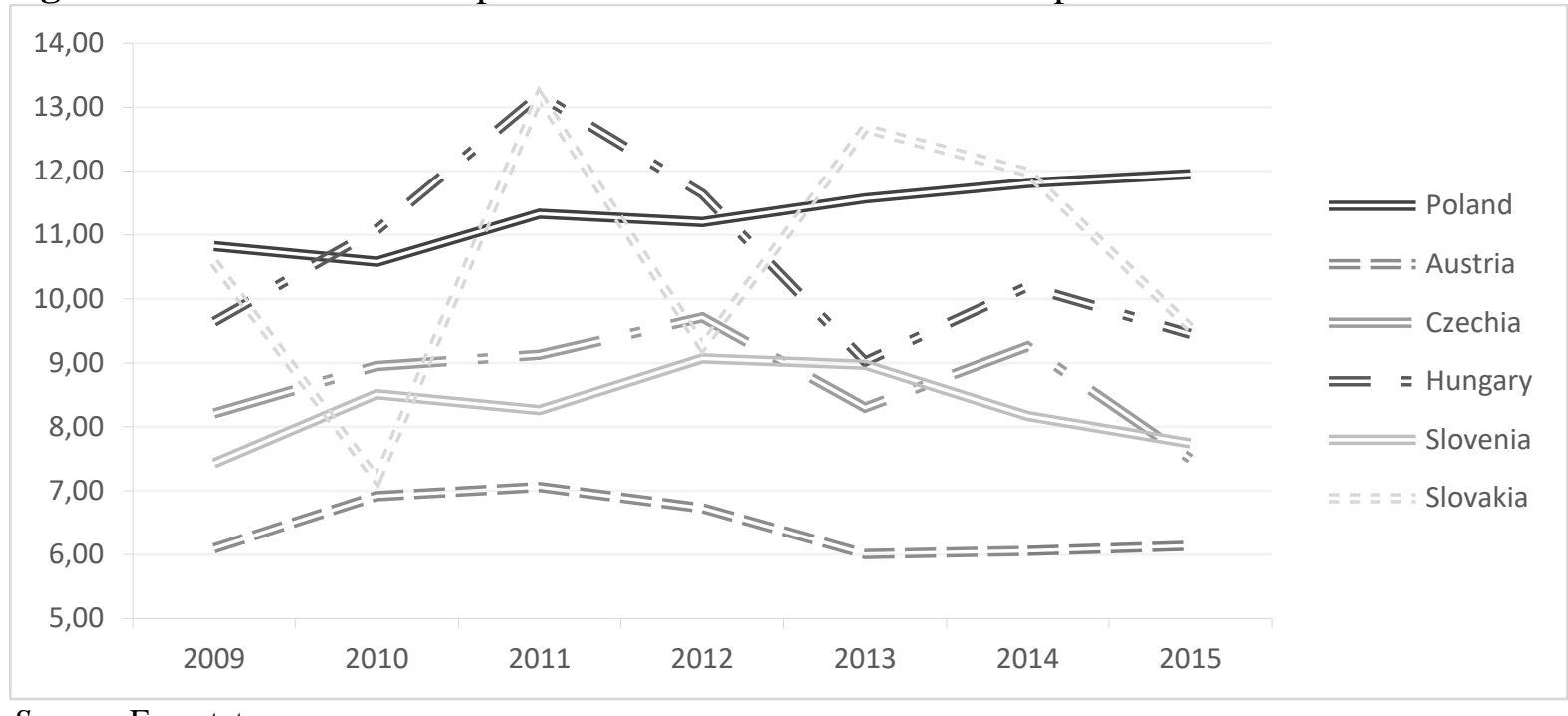

Source: Eurostat

\subsection{Taffler's bankruptcy model and correlation analysis}

Bankruptcy models indicate the financial condition of the company and its risk of potential bankruptcy. The models are based on real data from companies that have already gone bankrupt. Formulas are predicted to see if the company is going bankrupt or prospering. The forecast of bankruptcy can be detected several years before the actual bankruptcy. The financial health of companies is widely analysed by Taffler's bankruptcy model (1983). As explained in Taffler (1983), the first stage in constructing this model was to compute more than 80 carefully selected ratios from the accounts of all listed industrial firms failing between 1968 and 1976 and 46 randomly selected solvent industrial firms.

The correctness of the Taffler's model provides the study of Agarwal and Taffler (2007). This study describes a widely-used UK-based z-score model including publication of its ratio coefficients for the first time and explores its track record over the twenty-five-year period since it was developed. The paper demonstrates that the z-score model described, which was developed in 1983, has true failure prediction ability. The $\mathrm{z}$-score model continue to have significant value for financial statement users concerned about corporate credit risk and firm financial health. They also demonstrate the predictive ability of the underlying financial ratios when correctly read in a holistic way.

The Taffler's bankruptcy model is applied on the annual financial results of 391 public limited companies in Poland from 2006 to 2015.

Taffler's model:

$$
T Z=0.53 R 1+0.13 R 2+0.18 R 3+0.16 R 4
$$

$\mathrm{R} 1=\mathrm{EBIT} /$ short-term liabilities

$\mathrm{R} 2$ = current assets $/$ foreign capital

$\mathrm{R} 3=$ short-term liabilities / total assets

$\mathrm{R} 4=$ total sales $/$ total assets

The resulting company qualification is made according to the following ranges: 
$\mathrm{TZ}>0.3$ - low probability of bankruptcy of the company

$0.2<\mathrm{TZ}<0.3$ - grey zone of unmatched results

$\mathrm{TZ}<0.2$ increased probability of bankruptcy of the firm

Liou and Smith (2007) concluded that the number of bankruptcies is increasing during the economic recession, while in the conjunction period their number decreases. The Pearson correlation coefficients (2) is used to confirm Liou and Smithe's hypotheses. Correlation measures the strength of linear dependence between two variables.

The calculation of the Pearson correlation coefficient (Brooks, 2002) is then the following:

$$
r_{x y}=\frac{\sum\left(x_{i}-\bar{x}\right)\left(y_{i}-\bar{y}\right)}{(n-1) s_{x} s_{y}}
$$

where $x$ and $y$ are the sample means of $\mathrm{X}$ and $\mathrm{Y}$, and $\mathrm{s}_{\mathrm{x}}$ and $\mathrm{s}_{\mathrm{y}}$ are the corrected sample standard deviations of $\mathrm{X}$ and $\mathrm{Y}$. The Pearson correlation is +1 in the case of a perfect direct linear relationship, -1 in the case of a perfect inverse linear relationship, and some value in the open interval $(-1,1)$ in all other cases, indicating the degree of linear dependence between the variables. The closer the coefficient is to either -1 or 1 , the stronger the correlation between the variables.

\section{Results}

As a first step of my analysis, the Taffler's ratios had to be computed (R1, R2, R3, R4). The financial ratios needed for model are part of the annual reports of polish public limited companies. For the purpose of this paper, the Amadeus database was used. The calculated ratios were implemented to Taffler's bankruptcy model. According to result, the company qualification is made. If the resulting coefficient is higher than 0.3 , company has a low probability of bankruptcy. Taffler's coefficient between 0.2 and 0.3 indicates a grey zone and coefficient lower than 0.2 indicates increasing probability of bankruptcy. Number of polish public limited companies in each of the category is shown in Fig. 3.

Figure 3: Taffler's bankruptcy model

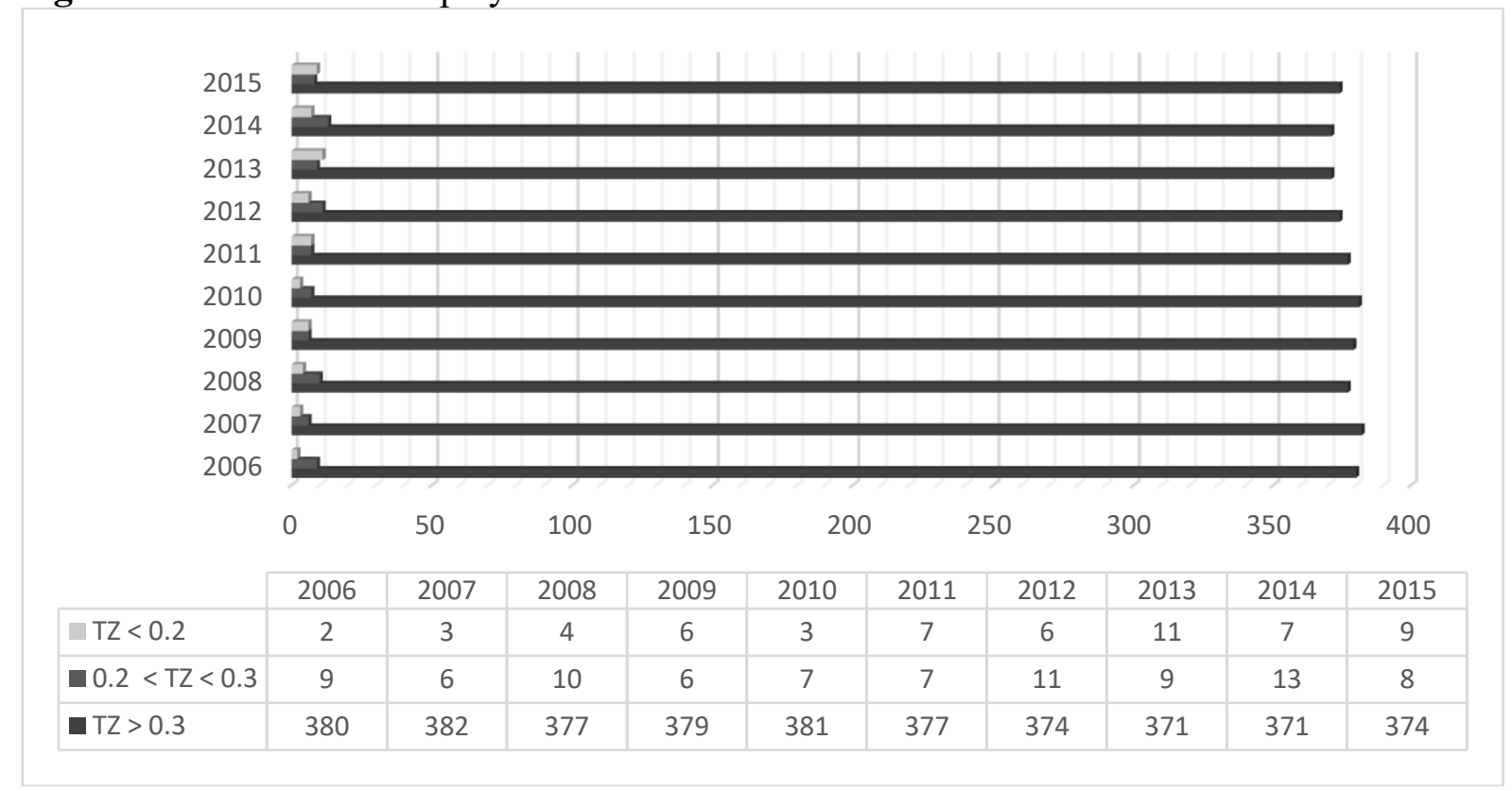

Source: author's calculations 
Last years are significant by increasing probability of bankruptcy in Polish public limited companies. Even if companies with financial problems is from $3 \%$ to $5 \%$ each year, the total number of companies in grey zone or in the zone of high probability of bankruptcy was 47 from 391 public limited companies in period 2006 - 2015. It means that more than $12 \%$ of public limited companies were threatened by bankruptcy. Public limited companies in Poland with a strong majority shareholder typically use more aggressive strategies than those with dispersed ownership. Polish companies mainly invest in Central and Eastern European countries, because of the limited financial resources of certain companies, as well as imperfect knowledge and experience. The list of companies with potential financial problems is in Appendix 1, together with their financial health, which is specified by results of Taffler's bankruptcy model. Continued reform, particularly in strengthening the independence of the judiciary and eradicating corruption, is needed to ensure greater economic dynamism.

The possible financial distress of mentioned companies brings with in an additional cost. These costs take the form of direct costs, which are various payments associated with dealing with financial distress such as court fees, payments to lawyers or crisis managers. These costs can be well quantifiable; as certain fixed amounts are paid. In addition to direct costs, they may also occur indirect costs that are already quantifiable much worse. Indirect costs are primarily presented as a lost profit, due to loss of customers. Although these costs can be quantified hardly, they can be assumed to achieve larger dimensions than direct costs. Indirect costs also often arise due to a conflict of interest creditors or shareholders and management. According to the study by Altman (2006), the industrial companies that were bankrupt have indirect cost of financial distress around $18 \%$ of total corporate assets.

Consistency of development of macroeconomic indicators and possible business problems or failures stemming from an unsatisfactory financial situation is possible at first glance obvious. Falling gross domestic product, this may mean a drop in sales and therefore a decline financial resources.

The relationship between economic situation in Poland and financial health of public limited companies is specified by Pearson correlation coefficient. Macroeconomic situation of Poland is representing by GDP growth per capita and for financial health, Polish public limited companies with middle or high probability of bankruptcy are chosen. The results of correlation coefficients captured in Table 1, shown 9 companies with statistical significant relationship.

Table 1: Pearson correlation coefficients

\begin{tabular}{|l|l|l|l|l|l|l|l|l|l|}
\hline Company & Lotos & Fabryka & Energa & MK Cra & JW Con & Targi & Regnon & PAK & Cynk \\
\hline Correl. & 0.6917 & 0.8215 & 0.6518 & 0.6342 & 0.6347 & 0.6619 & 0.7148 & 0.7450 & 0.6679 \\
\hline t-stat. & 2.7096 & 4.0756 & 2.4308 & 2.3199 & 2.3232 & 2.4977 & 2.8911 & 3.1592 & 2.5384 \\
\hline Prob. & 0.0267 & 0.0036 & 0.0412 & 0.0489 & 0.0487 & 0.0371 & 0.0202 & 0.0134 & 0.0348 \\
\hline
\end{tabular}

Source: author's calculations

\section{Conclusion}

The bankruptcy models are early warning systems. They indicate a possible threat of the financial distress of the company. These models were derived based on actual data from companies that have gone bankrupt or have flourished in the past. It is based on the assumption that the company has been experiencing certain anomalies for several years before bankruptcy, which contains indications of future problems that are characteristic of the vulnerable companies. Their design is appropriate not only for present and future decisions, they enable the management to separate and properly interpret indicators of potential future problems. The 
company's financial decision-making has a significant influence on the financial situation of the companies, but also the macroeconomic environment in which companies are located.

The aim of this paper was to indicate potential threat of the financial distress of selected public limited companies in Poland. The Taffler's bankruptcy model was applied on financial results of public limited companies in period 2006 - 2015. Poland's economy is considered to be one of the more resilient of the Central and Eastern European countries and is one of the fastest growing within the EU. Poland is the only European economy to have avoided the global finacial crises in 2009 and Poland's economy has demonstrated a fairly high degree of macroeconomic resilience. Structural reforms that have included trade liberalization, implementation of a competitively low corporate tax rate, and modernization of the regulatory environment have facilitated the transition to a market-oriented economy.

The results indicated that $12 \%$ of public limited companies in Poland had financial problems during observed period. Together with the highest companies' death rate in Central and Eastern European country, it could make a serious problem for business conditions in Poland.

According to Liou and Smith, the economic situation has a significant impact on financial health of companies. Pearson correlation coefficient does not confirm these hypotheses when results provide statistical significant relationship between financial health and GDP growth per capita only in 9 from 47 cases. On the contrary, correlation analysis confirmed that the number of bankruptcies is increasing during the economic recession, while in the conjunction period their number decreases. The positive correlation coefficients showed increasing Taffler's ratios in economic growth.

At the Polish economy's present stage of development, foreign direct investments are one of the key instruments not only for companies, but also for economic policy. The development of Polish enterprises and their position on global markets is a necessary condition for the transition to more profitable production specified by higher added value.

\section{Acknowledgement}

The research was financially supported by the Student Grant System of Silesian University in Opava within the "The effect of fundamental factors and corporate governance on stock prices" project. This support is greatly appreciated.

This research was financially supported by the Support of Science and Research in the Moravian-Silesian Region, Grant for Supporting talented Ph.D. Students of Silesian University in Opava. This support is greatly appreciated.

\section{References}

[1] AGARWAL, V. and R. TAFFLER, 2007. Twenty-Five Years of the Taffler Z-Score Model: Does It Really Have Predictive Ability? Accounting and Business Research, vol. 37, pp. 285-300.

[2] ALTMAN, E., 1968. Financial Ratios, Discriminant Analysis and the Prediction of Corporate Bankruptcy. Journal of Finance, vol. 23, issue 4, pp. 589-609.

[3] ALTMAN, E., 2006. Corporate Financial Distress and Bankruptcy. 3rd ed. New Jersey: John Wiley and Sons, Inc. ISBN 978-0-471-69189-1.

[4] BEAWER, W., 1966. Financial Ratios as Predictors of Failure. Journal of Accounting Research, vol. 4, issue 1, pp. 71-111. 
[5] BROOKS, Ch., 2002. Introductory Econometrics for Finance. Cambridge: Cambridge University. ISBN 0-52179367-X.

[6] FIJOREK, K. and M. GROTOWSKI, 2012. Bankruptcy Prediction: Some Results from a Large Sample of Polish Companies. International Business Research, vol. 5, issue 9, pp. 70-77.

[7] GRUSZCZYNSKI, M., 2004. Financial Distress of Companies in Poland. International Advances in Economic Research, vol. 10, issue 4, pp. 249-256.

[8] HAJDU, O. and M. VIRAG, 2001. A Hungarian Model for Predicting Financial Bankruptcy, Quarterly Journal of the Budapest University of Economic Sciences and Public Administration, vol. 23, issue 1-2, pp. 55-65.

[9] LIOU, D. and M. SMITH, 2007. Macroeconomic Variables and Financial Distress. Journal of Accounting, Business and Management, vol. 14, pp. 17-31.

[10] LIZAL, L., 2012. Determinants of Financial Distress: What Drives Bankruptcy in a Transition Economy? The Czech Republic Case. William Davidson working paper, No. 451.

[11] MOKHOVA, N. a M. ZINECKER, 2014. Macroeconomic Factors and Corporate Capital Structure. Journal Procedia-social and behavioral sciences, vol. 110, pp. 530-540.

[12] SENBET, L. W. and T. Y. WANG, 2012. Corporate Financial Distress and Bankruptcy: A survey. Foundations and Trends in Finance, vol. 5, issue 4, pp. 243-335.

[13] TAFFLER, R., 1983. The assessment of company solvency and performance using a statistical model. Accounting and Business Research, vol. 15, issue 52, pp. 295-308.

[14] WADHWANI, B. S., 1986. Inflation, Bankruptcy, Default Premia and Stock Market. The Economic Journal, vol. 96, issue 381, pp. 120-138. 


\section{Appendix}

\section{Appendix 1: The results of Taffler's bankruptcy model}

\begin{tabular}{|c|c|c|c|c|c|c|c|c|c|c|}
\hline Company & 2015 & 2014 & 2013 & 2012 & 2011 & 2010 & 2009 & 2008 & 2007 & 2006 \\
\hline ZESPÓt ELEKTROWNI PĄTNÓW-ADAMÓW-KONIN S. A. & $-0,52817$ & 0,266866 & 0,399005 & 0,464545 & 0,794047 & 0,706842 & 1,046643 & 0,565566 & 0,543114 & 0,640431 \\
\hline LOTOS PETROBALTIC S.A. & 0,192463 & 0,313542 & 0,320871 & 0,392837 & 0,346369 & 0,266905 & 0,204153 & 0,502735 & 1,871967 & 3,49764 \\
\hline POLNORD S.A. & 0,113952 & 0,264789 & 0,289422 & 0,46972 & 0,35332 & 0,387355 & 0,443638 & 0,558675 & 0,369368 & 0,268197 \\
\hline TRAMWAJE ŚLĄSKIE S.A. & 0,16482 & 0,172905 & 0,199436 & 0,238124 & 0,239037 & 0,214455 & 0,222166 & 0,216371 & 0,22923 & 0,232527 \\
\hline FABRYKA SAMOCHODÓW OSOBOWYCH S.A. & 0,179915 & 0,090015 & 0,152697 & 0,159961 & 0,251257 & 0,117934 & 0,098925 & 0,249713 & 0,345154 & 0,3245 \\
\hline PRZEDSIĘBIORSTWO FARMACEUTYCZNE JELFA S.A. & 0,181856 & 0,173147 & 3,521678 & 0,851196 & 2,09405 & 1,193576 & 1,044803 & 0,593095 & 1,129318 & 0,407461 \\
\hline JASTRZĘBSKI ZAKŁAD WODOCIĄGÓW I KANALIZACJI S.A. & 0,162413 & 0,184459 & 0,172222 & 0,164504 & 0,143622 & 0,156694 & 0,157036 & 0,138842 & 0,173137 & 0,466444 \\
\hline POLSKIE TATRY S.A. & 0,150662 & 0,158561 & 0,170102 & 0,159633 & 0,163609 & 0,444517 & 0,182761 & 0,171462 & 0,123469 & 0,117558 \\
\hline CCC S.A. & 0,136676 & 1,371002 & 1,789633 & 1,553179 & 1,639999 & 2,473527 & 2,568584 & 1,684106 & 1,569446 & 2,351127 \\
\hline POLIMEX - MOSTOSTAL S.A. & 0,378593 & 0,152674 & 0,357616 & 0,178943 & 0,449421 & 0,48238 & 0,537823 & 0,501557 & 0,512243 & 0,553855 \\
\hline KOMO - ROL S.A. & 4,302702 & 0,105343 & $-0,33287$ & 0,336122 & 0,370294 & 0,20002 & 0,452461 & 0,24612 & 3,301585 & 0,426838 \\
\hline ENERGA ELEKTROWNIE OSTROLĘKA S.A. & 0,56465 & 0,720497 & $-0,0215$ & 0,471213 & 0,615684 & 0,725921 & 0,757694 & 0,834929 & 0,802219 & 0,784925 \\
\hline ZELMER S.A. & 0,662154 & 2,296306 & 0,174032 & 0,434943 & 0,177775 & 2,280579 & 0,879628 & 0,915811 & 1,278459 & 1,071604 \\
\hline MOSTOSTAL PŁOCK S.A. & 0,54059 & 0,641843 & 0,033779 & 0,633473 & 0,19053 & 0,958672 & 0,800209 & 1,041234 & 0,92307 & 0,730059 \\
\hline MIEJSKI KLUB SPORTOWY CRACOVIA SPORTOWA S.A. & 0,468521 & 0,695234 & 0,15045 & 0,075658 & 0,208808 & 0,394985 & 0,317257 & 0,673829 & 0,591018 & 0,67461 \\
\hline BIURO STUDIÓW I PROJEKTÓW ENERGETYCZNYCH ENERGOPROJEKT - & 0,706803 & 0,742557 & 0,108708 & 0,94949 & 1,06943 & 1,639435 & 1,446198 & 1,305715 & 0,717794 & 0,900623 \\
\hline PBS FINANSE S.A. & 0,614659 & 0,86847 & 0,159066 & 0,436666 & 0,726121 & 0,54686 & 0,177105 & 0,594291 & 0,713247 & 0,229192 \\
\hline TRITON DEVELOPMENT S.A. & 0,460019 & 0,295784 & 0,258711 & 0,051174 & 0,432807 & 0,343548 & 0,343866 & 0,534784 & 0,252478 & 0,774279 \\
\hline STOCZNIA GDAŃSK S.A. & 1,027053 & 0,288364 & 0,342974 & 0,239646 & 0,143835 & 0,336882 & 0,528879 & 0,537375 & 0,342132 & 0,369725 \\
\hline IDEA FLEET S.A. & 0,345625 & 0,231278 & 0,428214 & 0,230335 & 0,19994 & 0,236568 & 0,753539 & 0,292167 & 0,455853 & 0,347992 \\
\hline CITONET - BYDGOSZCZ S.A. & 0,530396 & 0,629131 & 0,667133 & 0,674672 & $-0,21683$ & $-0,24713$ & $-0,22595$ & $-0,06614$ & 0,350964 & 0,278972 \\
\hline ECARD S.A. & 0,629299 & 0,635708 & 0,657522 & 0,639299 & 0,610392 & 0,205461 & $-0,23511$ & 0,014878 & 0,148802 & 0,475724 \\
\hline GTC KORONA S.A. & 1,401308 & 1,894615 & 0,772748 & 1,610641 & 1,879031 & 1,931223 & 1,219625 & 0,46168 & 0,3298 & 0,173277 \\
\hline J.W. CONSTRUCTION HOLDING S.A. & 0,207164 & 0,248922 & 0,302361 & 0,268011 & 0,304708 & 0,415872 & 0,380081 & 0,406727 & 0,478245 & 0,629691 \\
\hline SPÓŁKA ENERGETYCZNA JASTRZZ̨BIE S.A. & 0,263654 & 0,319495 & 0,368212 & 0,288435 & 0,397784 & 0,601309 & 0,581878 & 0,329471 & 0,349673 & 0,444018 \\
\hline TARGI KIELCE S.A & 0,237978 & 0,230339 & 0,215802 & 0,28939 & 0,350928 & 0,291957 & 0,721846 & 2,224483 & 1,794858 & 1,937012 \\
\hline ZASTAL S.A. & 0,202504 & 0,701659 & 0,276522 & 0,686903 & 0,591959 & 0,47152 & 0,456649 & 1,086398 & 0,463157 & 0,465947 \\
\hline ENERGA INVEST S.A. & 0,274829 & 1,604254 & 5,971117 & 0,613365 & 5,153198 & 3,084118 & 11,7495 & 1,925634 & 1,864339 & 1,862873 \\
\hline J\&S ENERGY S.A. & 0,292773 & 0,25857 & 0,251844 & 0,787823 & 0,792387 & 0,996967 & 0,855532 & 0,720489 & 1,066746 & 1,454299 \\
\hline RESBUD S.A. & 0,234693 & 0,218231 & 0,446003 & 0,312999 & 0,457465 & 0,731605 & 0,62321 & 0,977715 & 0,591533 & 0,813152 \\
\hline REGNON S.A. & 0,299106 & 0,39535 & 0,4789 & 0,311039 & 0,450662 & 0,619025 & 0,519549 & 0,675946 & 0,831171 & 0,836453 \\
\hline POLENERGIA S.A. & 0,402833 & 0,225804 & 0,376293 & 0,282049 & 0,45039 & 0,575483 & 0,487052 & 0,459129 & 0,669443 & 0,452738 \\
\hline PAK KOPALNIA WĘGLA BRUNATNEGO KONIN S.A. & 0,301097 & 0,274927 & 0,307805 & 0,27768 & 0,293778 & 0,461048 & 0,47192 & 0,506927 & 0,736126 & 0,666545 \\
\hline INWAR S.A. & 0,327775 & 0,279308 & 0,30767 & 0,307215 & 0,368755 & 0,665101 & 0,479857 & 0,258406 & 0,259119 & 0,272818 \\
\hline WYTWÓRNIA WODY ŹRÓDLANEJ POKCZYN ZDRÓJ S.A. & 0,315251 & 0,295386 & 0,284768 & 0,799353 & 0,86696 & 0,824078 & 0,789688 & 0,667758 & 0,56056 & 0,600256 \\
\hline AMK KRAKÓW S.A. & 0,45525 & 0,797503 & 0,248756 & 1,651318 & 0,476434 & 0,619047 & 0,288626 & 3,532313 & 0,46505 & 0,816919 \\
\hline FABRYKA WYROBÓW RUNOWYCH BIRUNA S.A. & 0,82852 & 0,801661 & 0,2979 & 0,31304 & 0,318684 & 0,288992 & 0,238193 & 0,321137 & 0,889454 & 0,373955 \\
\hline FAMAROL S.A. FABRYKA MASZYN ROLNICZYCH & 0,326872 & 0,30941 & 0,29335 & 0,28161 & 0,287354 & 0,464987 & 0,252592 & 0,250401 & 0,25635 & 0,260266 \\
\hline PBG S.A. & 0,40888 & 0,402148 & 0,450037 & 0,23259 & 0,368578 & 0,40606 & 0,425073 & 0,448759 & 0,358861 & 0,431505 \\
\hline CYNK MAL S. A. & 0,319665 & 0,399153 & 0,327664 & 0,254721 & 0,295918 & 0,344199 & 0,349907 & 0,673182 & 0,569028 & 0,72095 \\
\hline BIOTON S.A. & 0,477642 & 0,480809 & 0,444394 & 0,407771 & 0,287805 & 0,780247 & 0,328352 & 0,238547 & 0,43362 & 1,013025 \\
\hline ULMA CONSTRUCCION POLSKA S.A. & 1,046684 & 0,725846 & 0,476472 & 0,596578 & 0,676419 & 0,400782 & 0,241432 & 0,562921 & 0,808284 & 0,828162 \\
\hline DUON DYSTRYBUCJA S.A. & 0,921395 & 0,626873 & 0,594666 & 0,446578 & 0,343738 & 0,348361 & 0,403741 & 0,251894 & 0,250943 & 0,244146 \\
\hline AGENCJA ROZWOJU POMORZA S.A. & 0,818485 & 2,120513 & 1,46892 & 1,164137 & 0,589024 & 0,509614 & 0,863681 & 0,219867 & 0,249159 & 0,387908 \\
\hline PRZEDSIĘBIORSTWO BUDOWNICTWA WODNEGO W WARSZAWIE S.A. & 0,435429 & 0,544504 & 0,791641 & 1,202142 & 1,288061 & 1,064593 & 0,599678 & 0,275628 & 0,750399 & 0,574159 \\
\hline BULTEN POLSKA S.A. & 0,666581 & 0,76963 & 0,769206 & 0,765516 & 0,815688 & 0,69632 & 0,530969 & 0,442126 & 0,367991 & 0,276437 \\
\hline CITONET - KRAKÓW S.A. & 0,952946 & 0,904359 & 0,822837 & 0,704579 & 0,675456 & 0,608818 & 0,46295 & 0,326713 & 0,316931 & 0,223575 \\
\hline
\end{tabular}

Source: Author's calculations 